\title{
DETECTION OF HEPATITIS B VIRUS DNA IN SERA FROM 18 ALCOHOLIC CARRIERS OF "ANTI-HBC ALONE" AND RESPONSE TO A SINGLE DOSE OF HEPATITIS B VACCINE
}

\author{
Luiz Carlos Marques de OLIVEIRA' ${ }^{1}$, \\ Priscilla Dias Silva ABRAHÃ $\mathbf{O}^{2}$ and Sergio Borges de AMORIM²
}

\begin{abstract}
To evaluate the possibility of occult hepatitis B virus (HBV) infection in alcoholics carriers of "anti-HBc alone", and to verify the behavior of this serological pattern after a single dose of hepatitis B vaccine, 18 alcoholics who had this serological profile were evaluated by the polymerase chain reaction method, and 17 of them were vaccined. All were negative for HBV DNA. Nine (52.9\%) of those vaccined had anamnestic response, mainly those with positive anti-HBe (8/10; 80\%). "Anti-HBc alone" was compatible with low levels of anti-HBs in half of the patients, and probably with false positive results for anti-HBc in the others.
\end{abstract}

HEADINGS - Hepatitis B, immunology. Hepatitis B virus. Alcoholism. Hepatitis B core antigens.

\section{INTRODUCTION}

The term "anti-HBc alone" is defined by the presence of detectable anti-HBc without anti-HBs and HBsAg over time; in some instances, anti-HBe is also present but not $\mathrm{HBeAg}{ }^{(2)}$. It has been observed that the serological profile "anti-HBc alone" could signify a false positive result, a window phase of an acute HBV infection being resolved, late-stage immunity with a drop in anti-HBs serum levels, occult chronic infection confirmed by HBV DNA detectable by the polymerase chain reaction test (PCR) and the possible presence of HBsAg mutants; "anti$\mathrm{HBc}$ alone" is more frequently observed in individuals with concomitant infections by the hepatitis $\mathrm{C}$ virus (HCV) or by human immunodeficiency virus (HIV), in intravenous drug abusers and in immunocompromised individuals ${ }^{(2)}$.

Chronic alcoholism for many reasons can result in immunodeficiency, and so, the aim of this study was to verify if the serological profile of "anti-HBc alone" in alcoholics could signify a possible "occult infection", and also to verify the behavior of this serologic pattern after a single dose of hepatitis B vaccine.

\section{METHODS}

Twenty two alcoholic patients with the serological pattern of "anti- $\mathrm{HBc}$ alone" were prospectively evaluated.
Eighteen $(81.8 \%)$ of these patients were men and four $(18.2 \%)$ were women, whose mean age was $51.0 \pm 8.9$; they ingested more than 100 grams of ethanol per day for more than 10 years. At least 6 months after the initial tests, each one of these patients was submitted to new serological examinations for the usual HBV infection markers and also for anti-HCV and anti-HIV detection. Serum HBV DNA was determined in 18 patients who maintained the serological pattern of "anti-HBc alone", and 17 of these had received a single dose of the vaccine against HBV; eight of them had active alcoholism, i.e., they were drinking at the time of this study, and nine were in abstinence for more than 4 months before the vaccination.

The hepatitis $\mathrm{B}$ and hepatitis $\mathrm{C}$ markers were determined by the use of microparticle enzyme immunoassay (Abbott, AxSYM system, Wiesbaden, Germany) for qualitative detection of total anti-HBc (CORE), IgM anti-HBc (CORE $\mathrm{M}), \mathrm{HBsAg}$ (HBsAg V2), $\mathrm{HBeAg}(\mathrm{HBeAg} 2.0$ ), anti-HBe (anti-HBe 2.0), anti-HCV (HCV 3.0), and for quantitative determination of anti-HBs (AUSAB, positive values being $\geq 10 \mathrm{mIU} / \mathrm{mL}$ ). Anti-HIV 1 and 2 were determined using kits Abbott, AxSYM system HIV 1/2 $\mathrm{gO}$ and Biotest antiHIV TETRA ELISA - HIV-1/-2, Diasorin. HBV DNA was determined by the PCR: the HBV DNA of the serum samples was extracted using acid guanidinium thiocyanate-phenolchloroform according to the procedure previously described ${ }^{(1)}$. The amplification mix was submitted, according to the same parameters, to the reaction of "outer" and "nested":

\footnotetext{
This work was carried out at the "Ambulatório de Alcoolismo do Hospital de Clínicas da Universidade Federal de Uberlândia", Uberlândia, MG, Brazil Financial support: "Fundação de Assistência, Estudo e Pesquisa de Uberlândia (FAEPU)".

' ${ }^{1}$ Departamento de Clínica Médica, Faculdade de Medicina, Universidade Federal de Uberlândia (FAMED-UFU); ${ }^{2}$ Curso de Medicina FAMED/UFU, Uberlândia, MG Correspondence: Dr. Luiz Carlos Marques de Oliveira - Rua Gonçalves Dias, 455 - Bairro Tabajaras - 38400-288 - Uberlândia, MG, Brazil. E-mail: oliveiralcm@ufu.br
} 
$94^{\circ} \mathrm{C} / 30 \mathrm{sec}$ (denaturation), $64^{\circ} \mathrm{C} / 30 \mathrm{sec}$ (annealing), $72^{\circ} \mathrm{C} / 1 \mathrm{~min}$ (extension), increased by $72^{\circ} \mathrm{C} / 10 \mathrm{~min}$ for the fragment extension of the PCR. The oligonucleotides that were used as primers were: for "outer" OB2032R CTG ACT ACT AAT TCC CTG GAT CGT GGG TCT, OB1763E GCT TTG GGG CAT GGA CAT TGA CCC GTA TAA and for "Nested" OB2017R TAC TAT TCC CTG GAT GCT GGG TCT TCC AAA, OB1778E GGG CAA TGG ACA TTG ACC CGT ATA AAG AAT T. The PCR exams were done at the laboratory that is authorized by Brazilian "Sistema Único de Saúde" (SUS) for the realization of molecular exams in this macroregion, and the detection limit of the method was of 200 viral particles/mL.

Seventeen patients with "anti-HBc alone" were vaccinated with a $20 \mu \mathrm{g}$ dose of recombinant DNA vaccine against the HBV (Euvax B ${ }^{\circledR}$, LG Life Sciences, Korea) which was applied intramuscularly in the deltoid region and after 1 month, the serum anti-HBs of each patient was determined in order to evaluate the vaccination response, and serologic levels of anti-HBs which were more than $10 \mathrm{mIU} / \mathrm{mL}$ were taken as anamnestic response.

Diagnosis of liver cirrhosis was based on liver biopsy except in the case of those patients whose coagulation disorders did not permit this type of exam. In these cases, the diagnosis was based on clinical and laboratory criteria and on image exams (ultrasound and/or computerized tomography of the abdomen). Patients who did not have clinical signs of hepatopathy, who had normal or near normal laboratory exams, who had image exams that were normal or suggestive of fatty liver, were not submitted to liver biopsy.

For statistical analysis, the Student $t$ test was used for comparisons of the mean age of the patients; the exact Fisher test was used for comparisons of the frequency of vaccine response, and the analysis of simple logistic regression was used for analysis of the factors that could have interfered in this response.

Patients that used any drugs other than alcohol or immunosuppressive therapy or who had already been vaccinated against HBV were excluded from this study. The protocol for the research was approved by the Institutional Ethics Research Committee and informed consent was obtained from each individual.

\section{RESULTS}

In $3(13.6 \%)$ of 22 patients with "anti-HBc alone" the initial anti-HBc evaluation was a false positive result and in the other patient the anti-HBs became positive in the retest (anti-HBs level of $156 \mathrm{mUI} / \mathrm{mL}$ ). Of the 18 remaining patients who maintained the serological pattern of "anti-HBc alone", 10 were positive for anti-HBe, 2 were positive for anti-HCV and all were negative for HBeAg, anti-HIV and HBV DNA.

Table 1 contains the clinical and laboratorial data of each patient vaccinated against hepatitis $B$. Of the 17 who were vaccinated, $9(52.9 \%)$ had anamnestic response. There was a greater frequency of responders $(P<0.05)$ among the patients having positive anti-HBe $(8 / 10 ; 80 \%)$ than among those having negative anti-HBe $(1 / 7 ; 14.3 \%)$. The analysis of simple logistic regression showed that the presence of anti-HBe was an indication of a more probable vaccine response (odds ratio $=24[95 \%$ confidence interval, 1.74 a 380.82$], P=0,018)$.

The mean age (standard deviation) of the non responders $(58.1 \pm 7.8$ years) was greater $(P<0.01)$ than that of the responders $(45.1 \pm 6.0$ years $)$, and none of the patients who were over 60 years responded to the vaccination.

TABLE 1. Clinical data and response to hepatitis B vaccine in 17 of the 18 alcoholics having "anti-HBc alone". HBV DNA and anti-HIV were negative in all patients, and anti-HCV was positive in patients 6 and 14

\begin{tabular}{|c|c|c|c|c|c|c|c|c|}
\hline Patient & $\begin{array}{c}\text { Anti-HBs } \\
\text { post-vaccine }\end{array}$ & Anti-HBe** & Sex & BMI & Age (years) & Smoking & $\begin{array}{c}\text { Active } \\
\text { alcoholism }\end{array}$ & $\begin{array}{c}\text { Concurrent } \\
\text { disease }\end{array}$ \\
\hline 1 & 63.3 & + & M & 26.1 & 36 & + & - & - \\
\hline 2 & 5.2 & - & $\mathrm{M}$ & 33.9 & 61 & + & - & LC \\
\hline 3 & 0.3 & + & M & 27.0 & 62 & + & - & ACP \\
\hline 4 & 0 & - & $\mathrm{M}$ & 26.5 & 59 & + & + & - \\
\hline 5 & 18 & + & $\mathrm{M}$ & 31.8 & 47 & + & - & - \\
\hline 6 & 0 & - & $\mathrm{F}$ & 21.2 & 45 & + & - & LC \\
\hline 7 & 5.3 & + & M & 22.8 & 67 & + & + & CRF \\
\hline 8 & 32.7 & + & $\mathrm{F}$ & 23.4 & 53 & - & + & ACP \\
\hline 9 & 92 & + & M & 34.3 & 44 & + & + & LC \\
\hline 10 & 1000 & + & M & 21.3 & 37 & + & + & - \\
\hline 11 & 1.6 & - & $\mathrm{M}$ & 20.4 & 62 & + & + & LC \\
\hline 12 & 287 & + & $\mathrm{M}$ & 21.2 & 50 & + & - & LC \\
\hline 13 & 1.6 & - & M & 25.1 & 47 & + & + & - \\
\hline 14 & 0.7 & - & $\mathrm{M}$ & 34.5 & 62 & + & - & LC \\
\hline 15 & 168 & - & $\mathrm{M}$ & 24.4 & 48 & - & + & - \\
\hline 16 & 273.2 & + & $\mathrm{M}$ & 25.9 & 41 & + & - & LC \\
\hline 17 & 50.6 & + & $\mathrm{F}$ & 23.3 & 50 & - & - & - \\
\hline
\end{tabular}

$\mathrm{M}=$ male; $\mathrm{F}=$ female; $+=$ positive; $=$ negative; $\mathrm{BMI}=$ body mass index (weight $[\mathrm{kg}] /$ height $\left.[\mathrm{m}]^{2}\right) ; \mathrm{CRF}=$ chronic renal failure; $\mathrm{LC}=$ liver cirrhosis; $\mathrm{ACP}=$ alcoholic chronic pancreatitis; ${ }^{*} \mathrm{mlU} / \mathrm{mL}\left(<10=\right.$ non-response); ${ }^{*} \mathrm{P}<0.05-\mathrm{Th}$ simple logistic regression analysis showed that the presence of anti-HBe was indicative of anamnestic response 
Four $(50 \%)$ of the eight patients with active alcoholism, as well as, five $(55.6 \%)$ of the nine patients who were in abstinence were responders.

Seven of the 17 vaccinated patients had liver cirrhosis and $3(42.9 \%)$ of them were responders. Two patients had alcoholic chronic pancreatitis but without evident pancreatic insufficiency and another had chronic renal failure but was not on dialysis treatment.

\section{DISCUSSION}

In this study, occult HBV infection was not observed in the evaluated patients, and these results are in accordance with those found by ZIGNEGO et al. ${ }^{(5)}$ who showed that occult HBV infection is rare in Italian HBsAg-negative alcoholic patients. These same results, however, are different from those found by NALPAS et al. ${ }^{(3)}$ who reported a high percentage of serum positive HBV DNA in alcoholics who were negative for HBsAg and even in some who had none of the usual HBV infection markers.

$\mathrm{HBV} / \mathrm{HCV}$ co-infection could result in reduced $\mathrm{HBV}$ replication, thereby producing a decrease in serum HBsAg titers ${ }^{(2)}$. In the present study, occult infection by HBV was not observed in any of the two patients who had concomitant infection by HCV.

Most of the patients who responded to the vaccination were carriers of anti-HBe. The concomitant presence of anti-HBe in patients with "anti-HBc alone" increases the probability of anterior infection by HBV and of the presence of the anti-HBs in low titers. In this study, the only patient who had been laboratorially proven to have been infected by HBV had positive anti-HBe and had anamnestic response. None of the patients who were over 60 years responded to the vaccination and a similar fact had already been verified in a previous study in which alcoholic patients had been vaccinated ${ }^{(4)}$. This could explain why the mean age of the non responder patients was greater than that of the responders.

In this study, the frequency of responders among the patients with active alcoholism was similar to that of the patients in abstinence, and, in response to the conventional scheme, a similar fact was also observed in another previous study ${ }^{(4)}$. The frequency of response to hepatitis B vaccine was also similar among patients with and without liver cirrhosis, and the positive response in the liver cirrhosis patients was related to the presence of serum anti-HBe. Other factors considered as indicators of non response to the conventional scheme of vaccination against $\mathrm{HBV}$, such as body mass index and tobacco smoking could not be statistically analyzed because of the small number of patients evaluated in each subgroup. However, no interference of such factors was observed in the vaccination of alcoholic patients in one previous study ${ }^{(4)}$.

In conclusion, the PCR test with sensitivity over 200 copies $/ \mathrm{mL}$, which was used in this study, was not able to identify HBV occult infection in any of the patients. The anamnestic response, by approximately half the patients, manifested that "anti-HBc alone" was compatible with low anti-HBs serum levels; in the other half of the patients "anti-HBc alone" could have signified false positive anti-HBc results or occult infection which could not be detected by the PCR method which was used. Therefore, to better understand the clinical significance of the "anti-HBc alone" pattern in alcoholics, others studies should be conducted to evaluate serum HBV DNA with PCR of greater sensitivity and also to examine it in samples of liver biopsy.

Oliveira LCM, Abrahão PDS, Amorim SB. Pesquisa de DNA do vírus da hepatite B no soro de 18 alcoolistas portadores de "anti-HBc isolado" e resposta a uma dose da vacina para hepatite B. Arq Gastroenterol. 2008;45(3):252-4.

RESUMO - Para avaliar a possibilidade de infecção oculta pelo vírus da hepatite B em alcoolistas com "anti-HBc isolado" e a resposta a uma dose da vacina para a hepatite B, 18 alcoolistas com este perfil sorológico foram avaliados pelo método de reação em cadeia da polimerase e 17 deles foram vacinados. Todos tiveram negativos os exames para o VHB DNA. Nove $(52,9 \%)$ dos vacinados tiveram resposta anamnéstica, principalmente aqueles com anti-HBe positivo $(8 / 10 ; 80 \%)$. "Anti-HBc isolado" foi compatível com baixos títulos de anti-HBs em metade dos pacientes, e provavelmente com resultado falso-positivo para o anti-HBc nos demais.

DESCRITORES - Hepatite B, imunologia. Vírus da hepatite B. Alcoolismo. Antígenos do núcleo do vírus da hepatite B.

\section{REFERENCES}

1. Chomczynski P, Sacchi N. Single-step method of RNA isolation by acid guanidinium thiocyanate-phenol-chloroform extraction. Anal Biochem. 1987;162:156-9.

2. Grob P, Jilg W, Bornhak H, Gerken G, Gerlich W, Günther S, Hess G, Hüdig H, Kitchen A, Margolis H, Michel G, Trepo C, Will H, Zanetti A, Mushahwar I. Serological pattern "anti-HBc alone": report on a workshop. J Med Virol. 2000;62:450-5.

3. Nalpas B, Berthelot P, Thiers V, Duhamel G, Courouce AM, Tiollais P, Brechot C. Hepatitis B virus multiplication in the absence of usual serological markers. A study of 146 chronic alcoholics. J Hepatol. 1985;1:89-97.
4. Oliveira LCM, da Silva TE, Alves MH. Resposta à vacinação contra a hepatite B em alcoolistas sem cirrose hepática clinicamente evidente. Arq Gastroenterol. 2007;44:195-200

5. Zignego AL, Foschi M, Laffi G, Monti M, Careccia G, Romanelli RG, De Majo E, Mazzanti R, Buzzelli G, La Villa G, Gentilini P. "Inapparent" hepatitis B virus infection and hepatitis $\mathrm{C}$ virus replication in alcoholic subjects with and without liver disease. Hepatology. 1994;19:577-82. 